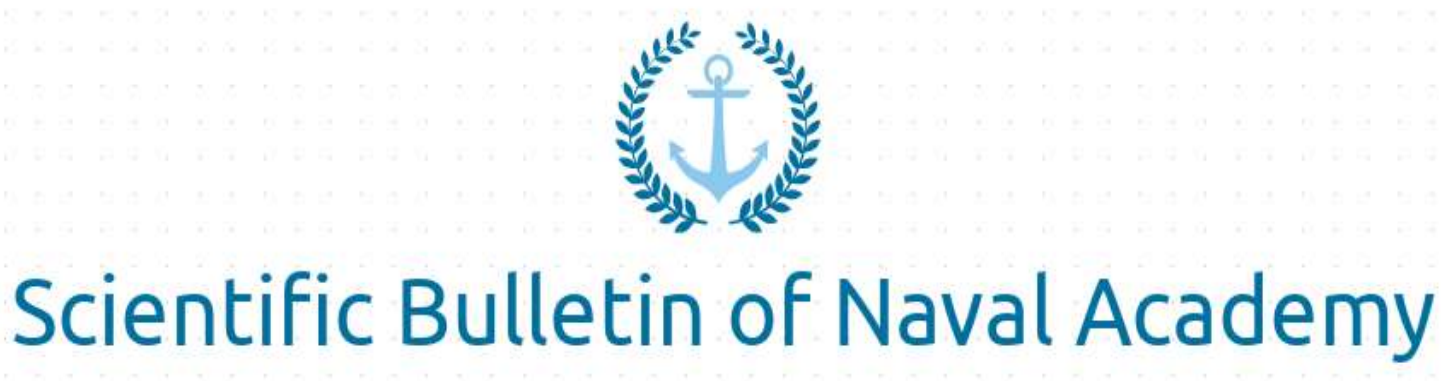

SBNA PAPER • OPEN ACCESS

The Assessment of Port Services Integration Within the Supply Chain. Connectivity Analysis Case on Constanta Port

To cite this article: Catalin Popa, Scientific Bulletin of Naval Academy, Vol. XXIII 2020, pg.278-286. 


\title{
The Assessment of Port Services Integration Within the Supply Chain. Connectivity Analysis Case on Constanta Port
}

\author{
Catalin Popa, Associate Professor PhD, catalin.popa@anmb.ro \\ Laura Zburlea, MSc, laura.zburlea@anmb.ro \\ 1 "Mircea cel Batran" Naval Academy, $1^{\text {st }}$ Fulgerului Street, Constanta, Romania
}

\begin{abstract}
The importance of port services integration into the global supply chain has been broadly approached in a broad range of scientific papers. Considering its updated technical and technological perspectives, most of the previous studies have been focused on the conceptualization of port supply chain integration as part of the global logistic chain. The purpose of the study is meant to consequently disclose by extensive literature review, the most common indicators that measure the effectiveness of the port services as to further depict how deeply integrated are the ports as functional component within the global supply chain, using the selected key performances indicators. In general, these indicators are metrics set up to monitor the cost, value, service, and waste, to illustrate the gap between planning and execution into a company's supply chain, the article seeking to put together most of the useful indicators in case of assessing the port logistic integration into the supply chain. Apart to the literature review, another research purpose, was to point the port evaluation pursuance support, on the example of Constanta port, suggesting the way to follow for deeper analysis in logistic integrative perspective.
\end{abstract}

Key word: port services, logistics, supply chain

\section{Introduction}

For long periods of time, the ports have been considered as the logistics hubs in transportation networks, were a great volume of cargoes and vessels are converging. Moreover, alongside the economic globalization phenomenon, the ports have become logistics centers, proving their competitive value playing an increasing role for stimulating the national, regional and international development. With the growing demand for integrated logistics services and increasing port competition, a port should effectively collaborate and cooperate with its supply chain partners, for providing value-added services to port users and to further contribute to the supply chain performance under logistic perspective [20], [15], [18], [20], [25].

The supply chain design is both addressed for port services suppliers (e.g. cargo services, ship services and value-added service or related) and customers (e.g. maritime and inland shipping lines and other multimodal transport operators). As integration can effectively stimulate the supply chain performance improving its competitiveness in terms of quality, transit time or information availability, the consideration of Port Service Supply Chain (PSSCs) integration become very relevant, as providing a better perspective about the functional integration with other organizations involved in cargo flow management. The integration process of the port into the global supply cannot be achieved overnight, and one method to accomplish is by using key performances indicators (KPIs). The industry-wide port performance framework is characterized by its ability to handle the movement of goods between the sea-side and land-side transporters [8]. 
This paperwork methodology is organized on three parts: the first section is destinated for literature review to disclose the state of art concepts of the ports perspective as relevant elements within the supply chain; the second section has sought to identify the most common port key performance indicators, based on literature resources as in the final part, to apply a synthetical analysis of the disclosed indicators on the example of the Constanta port (Romania) reflecting its services' rank of integration into the regional supply chain.

\section{The port services integration within the supply chain - literature review}

The "Supply Chain Integration" (SCI) is a complex process where all the involved entities are working as a single system to provide a product or a service, on a competitive, qualitative and timely manner to produce a higher satisfaction to the end user. The integration with suppliers and customers enables the participant companies to manage the flow of products, information and money through the supply chain network smoothly, efficient and effectively, providing access to multiple resources and capabilities for all the supply chain partners [21].

Schoenherr and Swink (2012) have conceptualized SCI as a result of three interconnected dimensions: suppliers, customers and internal integrated relations among all involved entities in inbound and outbound flows. To facilitate the effective coordination of flow of information, materials, money and decisions for increasing the customer value, the SCI must involve both inter-organizational (supplier and customer integration) and intra-organizational (internal integration) interfaces [21]. The port itself is necessary to be horizontally integrated in inbound and outbound flows with its suppliers and customers, but also internally on all vertical levels, within the port community network, serving the public, social and economic interest together, building a functional integrated chain of information and decisions on the level of port operators, the port authorities and all contributing stakeholders for the service added value.

a) Customer integration refers to close the collaboration and information sharing activities with key customers, allowing them to process their own transactions. In this way, the response to the customer is more efficient and effective with substantial savings on human resources [24]. The port services integration in this direction should target the information availability for all potential customers and their business analysis, to provide a timely understanding of all available facilities and their performance. The transparency and accountability of all available services for ships and cargo in the region, could better connect the port into the supply chain under and integrative perspective, the port administration playing a vital role in this perspective. A clear particularity of the port services is the diminished instruments available for the port operators in promoting their services, apart to the port community integrative policy, handled more or less exclusively by the public authorities, which could be defined as the catalyst of the port integration within the supply chain.

b) Supplier integration involves the coordination and information sharing activities with the key suppliers, allowing the suppliers and port operators to coordinate and to harmonize the decisions related to the inventory management, collaborative planning, traffic forecasting, stocks replenishment, port space management and cargo flows under an integrative manner [19]. Ideally the supplier should deliver their supplies directly to the place where are going to be used, or at least as close as possible. This requires that the port services provide should assure their suppliers with more access, training, and other resources than ordinary businesses. In essence, the relationship between the suppliers and customers should converge to a partnership approach. When speaking about the port services, the suppliers should be timely informed about the ships needs and cargo operation requirements, to be able to adjust their supplying items or services. The cargo services from inbound, as picking, packing or batching operations will be crucially for port integration within the supply chain, in reference with the client needs in the physical transfer of cargo, from the shipper to the end user.

c) Subsequently, the internal integration refers to the cross-functional intra-company collaboration and information sharing activities that occur via interconnected and synchronized processes and systems [12]. In case of port services, the stevedoring companies should prove their intra-departmental 
connectivity, but also the connectivity of all specialized departments with the respective port community entities.

The specialized term of "Port Supply Chain Integration (PSCI)" has been defined as a specific strategy undertaken by a seaport terminal in order to integrate various functions and organizations into functional network of supply, conceived to become an effective part of the regional and international supply chains [25].

Dyson (2000) claims that the performance measurements play an imperative role in enhancing the productivity, because it can define not only the current state of the system, but also its perspective and good will. Performance measurement helps to push the system into the projected direction through the effect exerted by the behavioral responses, towards these performance measures that exist within the system [9]. Furthermore, Marlow and Paixao (2003) have introduced the logistics concept of "lean" port operations as a key performance indicator in measuring the port efficiency and effectiveness. The authors have identified the new key performance indicators for modern ports as functional component of the "multimodal process" framework on international level. The identified indicators are focused on operations systems, infrastructure resources and logistics goals and strategies, seeking to meet the customer requirements in terms of reliability, information processing, cost, efficiency, and flexibility and responsiveness [16]. In the same perspective, Bichou and Gray $(2004,2005)$ advocated that in the era of globalization, it is important for ports to be considered as integral parts of supply chains, by serving and facilitating multimodal transport integration at all levels, pointing out that a logistic approach to measure the port performance become crucial for assessing the port efficiency [3], [4].

Searching on the same direction, Carbone and De Martino (2003) have identified four SCM components by interviewing in particular the French port operating companies:

- mutual relationships;

- supplied services;

- information and communication technologies;

- performance measurement [5].

In relation with the modern ports definition, Panayides and Song (2008) have described the integration of seaport/terminals within the supply chains as "Terminal Supply Chain Integration (TESCI)" and explain it as "the extent to which the terminal established system and processes undertakes relevant functions to becoming an integral part of the supply chain as opposed to being an isolated node that provides basic ship-shore operation". The authors have conceptualized TESCI in four components:

- information and communication systems (ICS);

- value added services;

- multimodal systems and operations;

- supply chain integration practices (SCIP) [17].

Consequently, considering the four components adopted from Carbone and De Martino (2003) and those depicted by Panayides and Song (2008), evaluating the degree of supply chain integration of terminals at Inchon port in Korea, Tongzon et al. (2009) have combined the prior identified variable into the following ones:

- relationship with users;

- value-added services;

- inter-modal infrastructure;

- channel integration practices [5], [17], [22].

Lately, Woo et al (2013) have applied five components to integrate the port services into the supply chain, considering both the ITC and the technological capabilities:

- information and communication systems (ICS);

- long-term relationships (LTR);

- value-added logistics services (VALS);

- inter-modal transport services (IMTS);

- supply chain integration practices (SCIP) [25]. 
In conclusion, due to such large and deep research, there are several well profiled models available in the literature, dealing with seaport performance and supply integration. The previous performance evaluation on literature has evaluated the seaport performance and partly neglected its overview into the global supply chain. To bridge this gap, using KPIs to measure the overall performance of the port services, the analysts are nowadays able to identify how properly integrated is the port and if its services are meeting or exceeding the required level of integration [2].

\section{Key performance indicators for port integration assessment. An overview of Constanta Port connectivity performance and potential}

\subsection{Theoretical approach on key performance indicators}

The common purposes of performance management seek to reduce costs and to improve efficiency and effectiveness. Therefore, a wide and complex range of indicators would be needed to properly assess the port system performance. By definition, a key performance indicator would be assigned for a certain type of performance measurement, on both quantitative and qualitative perspectives. The indicators are used by companies or organizations to support the effective assessment of their internal performance or, if the case, the performance of a particular activity in which they are engaged [6], [23], [26]. The objective of the present investigation is to depict by particular analysis the framework of performance measurement shaped and applied on Constanta Port case.

There are a number of key performance indicators which are generally considered crucial for practical assessment procedures, their identification being based on literature resources. As result, the major criterions which are often used regarding the assessment of the port terminal performance are listed below, as the basic grouping variable for the table no. 1 KPIs:

- management policy;

- $\quad$ supply side performance;

- organizational and institutional structure;

- terminal properties;

- level of service.

Furthermore, the KPIs were identified, selected and grouped under the above listed criterions [1], [7], [11], [13], [14].

Table 1. List of the most important key performance indicators

\begin{tabular}{|c|l|l|}
\hline Criterion & \multicolumn{1}{|c|}{ Indicator (KPI) } & \multicolumn{1}{c|}{ Description } \\
\hline \multirow{4}{*}{$\begin{array}{c}\text { Management } \\
\text { policy }\end{array}$} & Multimodality rate & Percentage of multimodal shipments over total \\
\cline { 2 - 3 } & Environmental burden & $\begin{array}{l}\text { GHC emissions, noise nuisance and traffic (low / medium } \\
\text { / high) }\end{array}$ \\
\cline { 2 - 3 } & Human safety and security & $\begin{array}{l}\text { Likelihood of human losses, i.e. annual number of human } \\
\text { injuries / fatalities per respective vehicle kilometers }\end{array}$ \\
\cline { 2 - 3 } & $\begin{array}{l}\text { Infrastructure and equipment } \\
\text { safety and security }\end{array}$ & $\begin{array}{l}\text { Likelihood of accidents, i.e. annual number of accidents } \\
\text { per respective vehicle kilometers }\end{array}$ \\
\hline $\begin{array}{c}\text { Organizational } \\
\text { and } \\
\text { institutional } \\
\text { structure }\end{array}$ & $\begin{array}{l}\text { Independence of terminal or } \\
\text { interchange management }\end{array}$ & $\begin{array}{l}\text { Independence from transport operators and local actors } \\
\text { (yes/no/partial) }\end{array}$ \\
\cline { 2 - 3 } & Fair an equal access & $\begin{array}{l}\text { Whether all companies have access to a terminal } \\
\text { interchange on equal conditions (yes/no/partial) }\end{array}$ \\
\cline { 2 - 3 } $\begin{array}{c}\text { Supply side } \\
\text { performance }\end{array}$ & Institutional complexity & $\begin{array}{l}\text { Number of institutional levels involved in the interchange } \\
\text { planning }\end{array}$ \\
\cline { 2 - 3 } & Employee productivity & $\begin{array}{l}\text { Ratio between flows and inputs, TEU transshipped per } \\
\text { employee and year }\end{array}$ \\
\hline $\begin{array}{c}\text { Terminal } \\
\text { properties }\end{array}$ & Equipment productivity & Total number of TEUs lifted per year and crane \\
\hline
\end{tabular}




\begin{tabular}{|c|c|c|}
\hline & $\begin{array}{l}\text { Saturation ratio (total cargo } \\
\text { tonnage) }\end{array}$ & $\begin{array}{l}\text { Ratio between actual volumes and maximum capacity } \\
\text { (daily average } \% \text { ) }\end{array}$ \\
\hline & Infrastructure productivity & Annual TEUs/Total terminal area \\
\hline & $\begin{array}{l}\text { Size and use of the maximum } \\
\text { capacity }\end{array}$ & $\begin{array}{l}\text { Annual TEUs/capacity of the container terminals (static } \\
\text { capacity), }\end{array}$ \\
\hline & Lines calling at the port & $\begin{array}{l}\text { Number of main lines (large intercontinental and inter- } \\
\text { oceanic lines with large ships and tonnage arriving in port } \\
\text { and with a large volume of goods). }\end{array}$ \\
\hline & Berth productivity & Annual throughput (TEU /meter of container quay). \\
\hline & $\begin{array}{l}\text { Capacity for receiving large } \\
\text { vessels }\end{array}$ & $\begin{array}{l}\text { Length of quay with }+14 \text { m depth }(m) / \text { Total quay length } \\
\text { (meters) - only container quay. }\end{array}$ \\
\hline & Expandability & $\begin{array}{l}\text { Potential for expandability ( } \% \text { increase compared to } \\
\text { today's capacity) }\end{array}$ \\
\hline & Distance from city center & $\begin{array}{l}\text { Number of kilometers from city center to interchange / } \\
\text { terminal }\end{array}$ \\
\hline & $\begin{array}{l}\text { Distance from commercial } \\
\text { areas }\end{array}$ & $\begin{array}{l}\text { Number of kilometers from terminal to nearest } \\
\text { commercial center }\end{array}$ \\
\hline & Distance from industrial zone & $\begin{array}{l}\text { Number of kilometers from interchange / terminal to } \\
\text { nearest industrial zone }\end{array}$ \\
\hline & Transshipment time & Time needed for loading / unloading per TEU \\
\hline & $\begin{array}{l}\text { Connection and distance to } \\
\text { primary motor-way network }\end{array}$ & $\begin{array}{l}\text { Direct, indirect or no access to nearest highway and } \\
\text { proximity }\end{array}$ \\
\hline & $\begin{array}{l}\text { Connection and distance to } \\
\text { primary railway network }\end{array}$ & Direct, indirect or no access and proximity \\
\hline & Connection to ports & Direct, indirect or no access and proximity \\
\hline & Connection to airports & Direct, indirect or no access and proximity \\
\hline & Handing cost & Average price paid per TEU transshipped (euro) \\
\hline & Punctuality & $\begin{array}{l}\text { Percentage of arrivals / departures within defined } \\
\text { tolerance for delay }\end{array}$ \\
\hline & Origin - destination time & Average time for last mile roundtrip in city center \\
\hline & Loss and damage & Percentage of shipments with loss or damage \\
\hline $\begin{array}{l}\text { Levels of } \\
\text { service }\end{array}$ & Technologic level & $\begin{array}{l}\text { Number of Information and Communication } \\
\text { Technologies (ICTs) that the port and terminals operators } \\
\text { offer to the port community: Wireless communications } \\
\text { (PMR for voice, Wi-Fi for data), Wireline } \\
\text { communications (PABX, FO network), RFID (Container } \\
\text { identification, container security, entrance system), OCR, } \\
\text { CCTV (Container/Truck identification, security), GNSS, } \\
\text { DGNSS (Crain guidance, container/truck positioning), } \\
\text { TOS (Command and control integration, logistic support), } \\
\text { Port Community System, Logistics Collaborative } \\
\text { Systems, B2B systems. }\end{array}$ \\
\hline & Information availability & $\begin{array}{l}\text { Existence of real time information and alerts inside the } \\
\text { terminal }\end{array}$ \\
\hline & Terminal integration level & $\begin{array}{l}\text { Proximity and access of terminal auxiliary services (e.g. } \\
\text { customs) }\end{array}$ \\
\hline & Level of automation & $\begin{array}{l}\text { Annual throughput in TEU per number of quayside cranes, } \\
\text { Percentage of automatized quayside cranes, Annual } \\
\text { throughput in TEU per number of yard gantries, } \\
\text { Percentage of automatized yard gantries, Annual } \\
\text { throughput in TEU per number of equipment for internal } \\
\text { movements (trucks, shuttle, etc.), Percentage of } \\
\text { automatized equipment for internal movements (trucks, } \\
\text { shuttle, etc.), Total percentage of automatized quayside }\end{array}$ \\
\hline
\end{tabular}




\begin{tabular}{|l|l|l|}
\hline & $\begin{array}{l}\text { cranes, yard gantries and equipment for internal } \\
\text { movements. }\end{array}$ \\
\hline
\end{tabular}

\subsection{The macro-variable of port connectivity}

The nowadays perspective of market integration on global scale, suggests a range of integrative indicators that could be considered in addition to the table no. 1 KPIs, as: manufacturing specialization, price competitiveness increased and trade boosting. From this perspective, become certain that a large synchronization of supply, distribution and marketing, span almost the entire globe, going even beyond the geographical boundaries. The integration process between the international users of port services demands the alternative promotion of maritime transportation services, which becomes an essential tool that facilitates and enable the flow of trade linkages between the nations on regional and global scale, proving a direct impact on the supply chain and the international business system. Transports and logistics services have a merging managerial ground, that allows specializing the international physical distribution operations, best reflected in the port services [10]. The ports are physical areas attached to the sea, ocean or river areas, connecting and networking the waterways, further being essentially considered as integrative entities. Ports are providing shelter to numerous vessels, with respective services for cargo and ships enabling constant or periodic transaction of a large variety of shipments. There are equipped with infrastructure and technical facilities of many kinds, that facilitate the cargo handling and forwarding, functioning as commercial node links between sea and land, as a valuable premise of intermodality [10]. Technically speaking, the port it is a convergence point between freight flows within supply chain networks.

Apart to its commercial function, the ports are known as catalysts which enhance the social and economic growth of a region, by not only based on trade variables, but also by serving a hub for social and public activities, proving a great significance to a nation, as it promotes the commercial welfare and the trade scenario enrichment [10].

\subsection{Analysis case of connectivity effectiveness of Constanta port}

As port importance revealed, together with the documented list of the most important key performance indicators applied in port services, in order to support integrating the port services into the global supply chain, the present research will further pursue to show which indicators could be applied to assess the Constanta port connectivity performance. The Port of Constanta is located at the crossroads of the trade routes, linking the markets of the landlocked countries from Central and Eastern Europe with the Transcaucasus, Central Asia and the Far East regions. It is the main Romanian port on the Black Sea, playing a highly important role as the transit node for the landlocked countries in the Central and SouthEast Europe, its strategic role being expressed by the following reasons:

- is considered a significant container traffic hub in the Black Sea and become a soundness hub for cereals trade on international level;

- provides good connections with all means of transportation: railway, road, river, airway and pipelines; - has modern facilities for passenger vessels and provide generous land availability for future expansion.

Primarily, these characteristics are comparable with those offered by the most important European and international ports, allowing the accommodation of tankers with capacity of $165,000 \mathrm{dwt}$ and bulk carriers of 220,000 dwt [27].

Secondly, Constanta Port is also considered a river port: the connection of the maritime port area with the Danube river being provided via Danube-Black Sea Canal, which represents one of the main key points of Constanta Port connectivity assessment. Moreover, due to low costs and important cargo volumes that can be carried, the Danube is one of the most advantageous modes of transport, an efficient alternative to the European rail and road congested transport [27].

Apart to the strategic perspective, the sample analysis of Constanta Port performance connectivity should be focused on intermodal perspective, as the most significant integrative variable of any port, as following: 
a) Railway connections - the port offers direct access from every terminal to the national and European railway network, through its own $300 \mathrm{~km}$ long railway system. Improvement works on the railway line between Constanta and Bucharest ensures competitive transit times, providing easier access to the Central European markets [27].

b) River connections - the Constanta port is connected to the Rhine-Danube TEN-T Corridor, which connects the two European commercial poles: Rotterdam and Constanta, creating an inland waterway from the North Sea to the Black Sea. The length of this waterway is $2414 \mathrm{~km}$ from Sulina, where the Danube flows into the Black Sea, to Kelheim, from where it continues through the Main-Rhine Canal, crossing Europe to the North Sea. On the Romanian territory, the length of the waterway is $1075 \mathrm{~km}$. The Constanta port connection with the Rhine-Danube Corridor through the Danube-Black Sea Channel creates a $4000 \mathrm{~km}$ shorter transport alternative for goods coming from the Far East and Australia via the Suez Canal and destined for Central Europe. According to the standards of the European Union and the United Nations, the Danube-Black Sea Canal is a class VI canal and a class "F" river canal. The canal, which comes under the administration of C.N. The Administration of Navigable Canals S.A., has a length of $64.4 \mathrm{~km}$, a width of $90 \mathrm{~m}$, a water depth of $7 \mathrm{~m}$ and $17.5 \mathrm{~m}$ under bridges. Located $35.4 \mathrm{~km}$ from the Danube, the northern arm of the Danube-Black Sea Canal provides the connection with Midia Port through two flood gates, at Ovidiu and Navodari. The northern arm has a length of $27.5 \mathrm{~km}$ and a width of 45-50 m, with minimum water depths of $5.5 \mathrm{~m}$. Easy access to Central Europe is ensured by the good navigable conditions of the Lower Danube and the low number of locks (only 4 flood gates) on the sector between Constanta and Budapest. [27].

c) Roads connections - all entry / exit gates in the Constanta port are connected to the national and European road network, the road connection having a strategic importance, thus making the connection between the Constanta port and the countries without access to the sea in Central and Eastern Europe. There is a permanent concern for the improvement of the port road network and for the intensification of the road traffic. Thousands of trucks benefit from the facilities offered by the Constanta port, ensuring a fast and flexible transport for all types of goods in the "door to door" transport system. The total length of the roads is approx. $100 \mathrm{~km}$. The A2 highway, connects Bucharest with the Constanta port and has a distance of $203 \mathrm{~km}$ [27].

d) Pipelines - the Constanta port is connected to the national pipeline network, thus ensuring the ideal connection with the main Romanian refineries. The network of pipes inside the port consists of underground and above-ground pipes of $15 \mathrm{~km}$ and a total length of pipes of $50 \mathrm{~km}$ [27].

e) Airlines connectivity- Mihail Kogalniceanu Airport is located $20 \mathrm{~km}$ away from Constanta port. It is an international airport that represents an air gateway with special implications for zonal and regional development [27].

Consequently, the IT activities carried out in the past years were oriented on the following directions: ensuring information security in the operation of the company's integrated information system; ensuring the operation in optimal conditions and without interruptions of the existing IT infrastructure. Though, the information system must be modernized to ensure its harmonization with the new business requirements of the company and allowing continuous and real-time monitoring of economic activity, through reporting and analysis and provide the necessary elements to substantiate decisions and control [27].

As line services, the most important container lines ensure a fast and efficient connection between the Constanta port and the most important ports in the world. The containerized transports performed by the line services that connect the Romanian port and the ports from the Far East have the effect of transforming the port of Constanta into a distribution port both for the Black Sea region and for Central and Eastern Europe. The distances between the ports in the Far East and the Port of Constanta are shorter compared to the distances between them and the North Sea. Obviously, a shorter sea route means lower costs and transport times. In the Constanta port there are four container terminals, which offer customers a series of facilities for operation, as well as natural depths that allow the operation of the largest ships that can pass through the Bosphorus Strait. 


\section{Conclusions}

The present analysis has sought to reveal the major KPI that can be applied for assessing the port performance, selecting in the way of the literature review the most important variables feasible to be considered in expressing the port services efficiency and effectiveness in micro and macro perspectives. To provide a short example of connectivity evaluation, Constanta Port has been chosen, the evaluation having on the ground the connectivity parameters on all meaning of interconnections provided by land, air or sea. The following stages of research will inquire a deeper analysis to be provided, with summing up a wider spectrum of key performance indicators. The main conclusion is that in a globalized business environment, the ports can bring a relevant added value to the supply chain performance, as an important variable of competitiveness.

\section{References}

[1] Andersen J., Eidhammer O., Gogas M., Papoutsis K., Nathanail E. (2014). Demonstration assessments. Deliverable 5.1. STRAIGHTSOL - Srategies and measures for smarter urban Freight Solutions;

[2] Bentaleb, Fatimazahra \& Mabrouki, Charif \& Semma, Elalami. (2015), Key Performance Indicators Evaluation and Performance Measurement in Dry Port-Seaport System: A Multi Criteria Approach, Journal of ETA Maritime Science. 3. Pages 97 - 116. 10.5505/jems.2015.88597;

[3] Bichou, K. and Gray, R. (2004), A logistics and supply chain management approach to port performance measurement, Maritime Policy \& Management, Vol. 31 No. 1, pp. 47-67;

[4] Bichou, K. and gray, R. (2005), A critical review of conventional terminology for classifying seaports, Transportation Research Part A: Policy and Practice, Vol. 39 No. 1, pp. 75-92;

[5] Carbone, V. and De Martino, M. (2003), The changing role of ports in supply-chain management: an empirical analysis, Maritime Policy \& Management, Vol. 30 No. 4, pp. 305-320;

[6] Cerutti, O. and Gattino, B. (1992), Indicateurs et tableaux de bord, AFNOR, Paris;

[7] Christiansen, P., Johansen, B.G., Andersen, J., Eidhammer, O. (2012). Case studies: Results and synthesis. Deliverable 5.2. CLOSER - Connecting Long and Short-distance networks for Efficient transport;

[8] Cullinane, K. and Wang, T., The efficiency analysis of container port production using DEA panel data approaches, OR spectrum, vol. 32, pp. 717-738, 2010;

[9] Dyson, R. G. (2000), Performance measurement and data envelopment analysis - Ranking are rank, OR Insight, 13(4), 3-8;

[10] García, Beatriz. (2013), Ports: Definition and study of types, sizes and business models. Journal of Industrial Engineering and Management. 6. 10.3926/jiem.770;

[11] Gogas, Michael \& Adamos, Giannis \& Nathanail, Eftihia. (2017), Assessing the performance of intermodal city logistics terminals in Thessaloniki. Transportation Research Procedia. 24. 17-24. 10.1016/j.trpro.2017.05.061;

[12] Han, C., Assessing the impacts of port supply chain integration on port performance, The Asian Journal of Shipping and Logistics, Volume 34, Issue 2, 2018, Pages 129-135, ISSN 2092-5212;

[13] Nathanail E., Gogas M. (2005). Spatial planning - Development of nodal points and terminals. Deliverable 4. IMONODE - Efficient Integration of cargo transport modes and nodes in CADSES area; [14] Nathanail E., (2007), Developing an integrated logistics terminal network in the CADSES area. Transition Studies Review, May 2007, Volume 14, Issue 1, pp 125-146;

[15] Notteboom, T.E. and Rodrigue, J.P. (2005), Port regionalization: towards a new phase in port development, Maritime Policy \& Management, Vol. 32 No. 3, pp. 297-313;

[16] Paixao, A.C. and Marlow, P.B. (2003), Fourth generation ports - a question of agility?, International Journal of Physical Distribution \& Logistics Management, Vol. 33 No. 4, pp. 355-376;

[17] Panayides, P.M. and Song, D.W. (2008), Evaluating the integration of seaport container terminals in supply chains, International Journal of Physical Distribution \& Logistics Management, Vol. 38 No. 7 , pp. 562-584; 
[18] Pettit, S.J. and Beresford, A.K.C. (2009), Port development: from gateways to logistics hubs, Maritime Policy \& Management, Vol. 36 No. 3, pp. 253-267;

[19] Ragatz, G.L., Handfield, R.B., Peterson, K.J., (2002), Benefits associated with supplier integration into new product development under conditions of technology uncertainty, Journal of Business Research Vol. 55, No. 5, pp. 389-400;

[20] Robinson, R. (2002), Ports as elements in value-driven chain systems: the new paradigm, Maritime Policy \& Management, Vol. 29 No. 3, pp. 241- 255;

[21] Schoenherr, T. and Swink, M., (2012), Revisiting the arcs of integration: Cross-validations and extensions, Journal of Operations Management, 30 (1-2), 99-115;

[22] Tongzon, J., Chang, Y.T. and Lee, S.Y., (2009), How supply chain oriented is the port sector?, International Journal of Production Economics, 122 (1), 21-34;

[23] Turi, A., Goncalves, G., \& Mocan, M. (2014), Challenges and Competitiveness Indicators for the Sustainable Development of the Supply Chain in Food Industry. Procedia-Social and Behavioral Sciences, 124, 133-141;

[24] Wong, C.Y., Boonitt, S., Wong, C.W.Y., (2011), The contingency effects of environmental uncertainty on the relationship between supply chain integration and operational performance, Journal of Operations Management Vol. 29 No. 6, pp. 604-615;

[25] Woo, S.H., Pettit, S., Beresford, A., (2013), An assessment of the integration of seaport into supply chain using a structural equation model, Supply Chain management, Vol. 18, No. 3, pp. 235252 ;

[26] Woxenius, J. (2012), Directness as a key performance indicator for freight transport chains. Research in Transportation Economics, 36(1), 63- 72;

[27] https://www.portofconstantza.com/. 